\title{
Pelayanan Kefarmasian di beberapa Apotek di Indonesia pada Era Pandemi Covid-19
}

\author{
Muhammad Mu'amar Fathoni, Rizella Fitriani, Fidya Dwi Lestari, Vita Maulinda Asa Angembani, Amalia Tusholecha, \\ Winda Fatmasari, Alyajilan, Shafa Azaria, Yuliana, Nadya Amaliah, Safira Izza Maharani, Elida Zairina* \\ Departemen Farmasi Komunitas, Fakultas Farmasi, Universitas Airlangga \\ Gedung Nanizar Zaman Joenoes Kampus C, Jl. Ir. Soekarno, Surabaya 60115, Indonesia \\ *E-mail: elida-z@ff.unair.ac.id
}

\begin{abstract}
ABSTRAK
COVID-19 telah mempengaruhi aspek kesehatan. Apoteker perlu merumuskan strategi dan inovasi dalam menghadapi pandemi ini untuk memberikan pelayanan kefarmasian kepada masyarakat. Penelitian ini bertujuan untuk mengetahui dampak, pelayanan kefarmasian, dan inovasi pelayanan kefarmasian di apotek Indonesia pada masa pandemi COVID19. Penelitian dilakukan dengan cara observasional dan desain cross-sectional. Data dikumpulkan melalui kuesioner yang disebarkan secara daring. Sebanyak 96 apoteker berpartisipasi dalam penelitian ini. Data dianalisis secara deskriptif dan distribusi data ditampilkan berdasarkan frekuensi dan persentase dari hasil kuesioner. Hasil penelitian menunjukkan bahwa pandemi COVID-19 ini berdampak pada $(60,4 \%)$ pelayanan apotek di Indonesia karena terjadi peningkatan permintaan beberapa produk farmasi (suplemen, vitamin, dan alat kesehatan) yang dapat menekan sistem rantai pasokan obat. Pelayanan kefarmasian saat COVID-19 sudah diterapkan oleh beberapa apotek di Indonesia $(31,25 \%, \mathrm{n}=30)$ sesuai Pedoman Kemenkes RI terkait Pedoman Kesiapsiagaan COVID-19 Rev 02 Tahun 2020. Selain itu, beberapa apotek di Indonesia $(71,88 \%, \mathrm{n}=69)$ telah menerapkan E-pharmacy, pembayaran non tunai, layanan resep dan swamedikasi secara daring, serta pengiriman obat ke rumah pasien di masa pandemi COVID-19. Dampak pandemi COVID-19 pada pelayanan kefarmasian di apotek yakni penerapan e-pharmacy dan sebagian besar apotek telah menerapkan prosedur operasional yang sesuai.
\end{abstract}

Kata Kunci: Apotek, COVID-19, Pelayanan Kefarmasian, Apoteker, Indonesia

\begin{abstract}
COVID-19 has affected health aspects, therefore pharmacists need to formulate strategies and innovations to provide pharmaceutical services. This study aimed to identify the impact, pharmaceutical services, and creation of pharmaceutical services on community pharmacies in Indonesia during the COVID-19 pandemic. This observational study was designed as a cross-sectional. Data were collected using a questionnaire that circulated online through a social media. A total of 96 pharmacists participated in this study. Data were analyzed descriptively and was shown based on the frequency and percentage of the questionnaire results. The COVID-19 pandemic impacted (60.4\%) pharmacy services in Indonesia due to an increase in purchasing of several supplements, vitamins that could suppress the drug supply chain system. Pharmaceutical service in COVID-19 has been implemented by community pharmacies (31.25\%, $\mathrm{n}=30)$ according to the Indonesian Ministry of Health Guidelines about Preparedness Guidelines for COVID-19 Rev 02 of 2020. Besides, a few pharmacies in Indonesia (71.88\%, n=69) implement E-pharmacy, including non-cash payment, prescription services and self-medication online, and sending medicines to patient homes during the COVID-19. The impact of the COVID-19 pandemic on pharmaceutical services is e-pharmacy implementation and most pharmacies have implemented appropriate operational procedures.
\end{abstract}

Keyword: Community Pharmacy, COVID-19, Pharmaceutical Service, Pharmacist, Indonesia 


\section{PENDAHULUAN}

Pada 11 Februari 2020, WHO mengumumkan nama resmi untuk penyakit yang menjadi wabah virus baru yang pertama kali diidentifikasi di Wuhan, Cina. Nama penyakit ini adalah Coronavirus 2019 (COVID19). COVID-19 merupakan penyakit yang disebabkan oleh virus corona yang menyerang saluran pernapasan pada semua usia (World Health Organization, 2020). Menurut Hedima, et al. (2020) krisis kesehatan masyarakat global akibat COVID-19 ini telah mempengaruhi praktik perawatan kesehatan di seluruh profesi. Pandemi COVID-19 menempatkan tuntutan yang luar biasa dan berkelanjutan pada sistem kesehatan dan penyedia layanan masyarakat yang penting. Oleh karena itu praktisi medis dan farmasi harus beradaptasi dan mengadopsi perubahan peran profesional di tengah sistem perawatan kesehatan yang dinamis (Fallucchi et al., 2020).

Pelayanan kefarmasian adalah suatu pelayanan langsung dan bertanggung jawab kepada pasien yang berkaitan dengan sediaan farmasi dengan tujuan untuk meningkatkan mutu kehidupan pasien (Permenkes No. 35 tahun 2014 Tentang Standar Pelayanan Kefarmasian di Apotek). Pelayanan kefarmasian di farmasi selama COVID-19 harus memiliki sistem yang dapat mencegah penularan penyakit sekaligus dapat memenuhi kebutuhan pasien. Apotek harus berfungsi sebagai pendukung kuat obat-obatan pasien dan pasokan alat pelindung. Apoteker harus siap untuk memberikan layanan kefarmasian yang terampil dan efektif bagi populasi pasien untuk memastikan keamanan pengobatan dan mempromosikan pengendalian pandemi COVID-19 secara keseluruhan (Zheng et al., 2020).

International Pharmaceutical Federation (2017) telah menerbitkan pedoman sementara untuk tenaga kerja farmasi yang berisi tanggung jawab profesional apoteker selama pandemi COVID-19. Di dalam pedoman tersebut disebutkan bahwa peran farmasis terbagi menjadi 4, yaitu Prevention (langkah-langkah untuk mengurangi risiko kesehatan yang ditimbulkan oleh pandemi), Preparedness (tindakan untuk memastikan tanggapan tepat waktu dan efektif), Response (tindakan segera sebagai respons terhadap pandemi), dan Recovery (tindakan untuk kembali ke aktivitas normal pasca-pandemi).

Sebagai konsekuensi dari pandemi COVID-19 dan terbitnya pedoman sementara, terjadi sedikit perbedaan pada pelayanan kefarmasian terutama di apotek. Penerapan jaga jarak selama pandemi COVID19 membuat apotek membatasi kontak langsung dengan pasien dan jumlah kunjungan dalam satu waktu. Kondisi ini secara tidak langsung juga memberikan perubahan pelayanan terutama dalam pelayanan untuk memastikan penggunaan obat yang aman dan efektif. Ada beberapa pelayanan yang dilakukan oleh apotek selama pandemi COVID-19 misalnya pengalihan resep fisik (kertas) ke elektronik, penambahan fasilitas pengambilan obat mandiri, dan peningkatan pelayanan pengiriman obat ke rumah pasien. Selain itu, untuk meminimalkan kerumunan, beberapa apotek mengizinkan pasien untuk menebus ulang resep obat setelah pasien menerima informasi dari apotek terkait jadwal penebusan obat (Koster et al. 2020).

Beberapa negara menerapkan e-pharmacy sebagai sistem pelayanan kefarmasiannya dimasa pandemi COVID-19. E-pharmacy adalah apotek yang beroperasi melalui internet dan mengirim pesanan kepada pelanggan melalui surat elektronik (e-mail) atau portal web farmasi online. Situs e-pharmacy dapat berupa blog kesehatan yang memberikan informasi tentang obat-obatan yang dibeli seperti indikasi, efek samping, dosis, dan informasi tentang berbagai kondisi medis untuk meningkatkan pengetahuan dan kesadaran pasien (Singh et al., 2020).

Beberapa negara telah melakukan perubahan atau modifikasi terkait pelayanan kefarmasian di apotek. Di Indonesia telah dikeluarkan standar prosedur operasional terkait Pedoman Kesiapsiagaan COVID-19 Rev 02 Tahun 2020. Oleh karena itu, penelitian ini bertujuan untuk mengetahui dampak, pelayanan kefarmasian, dan inovasi pelayanan kefarmasian di apotek Indonesia pada masa pandemi COVID-19. Manfaat penelitian diharapkan dapat diperoleh gambaran tentang pelaksanaan pelayanan kefarmasian di apotek dalam memenuhi kebutuhan masyarakat selama COVID-19.

\section{METODE PENELITIAN}

Penelitian ini merupakan penelitian
observasional dengan desain cross-sectional. Responden pada penelitian ini adalah apoteker yang berpraktik di apotek di Indonesia. Pengambilan data pada penelitian ini dilakukan secara daring menggunakan kuesioner yang didesain menggunakan platform googleform ${ }^{T M}$. Kuesioner dikirim melalui aplikasi chatting (whatsapp ${ }^{T M}$ ) dan media sosial (instagram $^{T M}$ ) pada tanggal 8 Oktober 2020 hingga 15 Oktober 2020.

Sebanyak 110 partisipan mengisi kuesioner yang disebarkan secara daring dengan metode pengambilan sampel adalah accidental sampling, akan tetapi terdapat 14 responden yang tidak memenuhi kriteria inklusi karena bukan apoteker yang praktik di apotek melainkan apoteker rumah sakit dan tenaga teknis kefarmasian. Oleh karena itu, hanya 96 responden apoteker yang dimasukkan dalam analisis data, dengan posisi sebagai apoteker pemilik dan/atau pengelola, atau apoteker pendamping di apotek yang memberikan pelayanan selama masa pandemi COVID19 di Indonesia. 


\section{Instrumen survei}

Kuesioner dirancang berdasarkan studi literatur mengenai dampak COVID-19 terhadap pelayanan kefarmasian di apotek, sistem pelayanan kefarmasian dan pengembangan metode pelayanan kefarmasian di apotek selama masa pandemi COVID-19. Dalam pengumpulan data responden digunakan kuesioner dengan metode kombinasi antara pertanyaan terbuka dan tertutup. Pertanyaan tertutup menggunakan metode Guttman, tanggapan dari responden berbentuk jawaban tegas seperti "ya" atau "tidak" dan "pernah" atau "tidak pernah" (Bahrun et al., 2017). Kuesioner terdiri dari identitas responden, dampak yang dialami apoteker selama masa pandemi COVID-19 (terdiri dari 8 pertanyaan tertutup dan 3 pertanyaan terbuka), standar prosedur operasional (SPO) yang diterapkan apotek di masa pandemi COVID-19 (terdiri dari delapan pertanyaan tertutup dan satu pertanyaan tertutup), dan metode pelayanan kefarmasian selama masa pandemi COVID-19 (terdiri dari empat pertanyaan tertutup dan dua pertanyaan terbuka). Total pertanyaan pada kuesioner adalah 26 pertanyaan.

Kuesioner yang digunakan telah dilakukan face validity yaitu penilaian secara subjektif mengenai validitas prosedur yang digunakan (Santamaría-Gadea et al., 2021). Validasi kuesioner meliputi tampilan, bahasa, dan isi pertanyaan yang digunakan sebelum dilakukan pengambilan data di lapangan dengan melibatkan mahasiswa profesi apoteker baru saja menyelesaikan studinya sebanyak 26 orang. Semua partisipan yang terlibat memberikan persetujuan (informed consent) sebelum melakukan pengisian kuesioner.

\section{Teknik analisis data}

Data responden yang diperoleh dianalisis menggunakan software SPSS versi 22. Karakteristik demografi dan tanggapan terhadap berbagai pertanyaan dianalisis secara deskriptif. Data demografi disajikan dalam bentuk tabel dan distribusi data ditampilkan secara persentase dan frekuensi. Sedangkan tanggapan terhadap pertanyaan tertutup disajikan dalam bentuk diagram batang dan untuk pertanyaan terbuka disajikan dalam bentuk pie chart. Distribusi data dari kedua diagram ditampilkan secara persentase

\section{HASIL DAN PEMBAHASAN}

\section{Demografi}

Jumlah sampel yang digunakan dalam survei ini adalah 96 responden. Dari Tabel 1 dapat diketahui bahwa mayoritas responden adalah wanita $(n=85$; $88,5 \%)$, dengan rentang umur 26-35 tahun $(n=55$; $57,3 \%$ ) dan rata-rata umur 32 tahun. Mayoritas posisi responden di apotek adalah sebagai apoteker pengelola apotek $(n=53 ; 55,2 \%)$ dan mayoritas mempunyai pengalaman kerja selama 2-5 tahun $(\mathrm{n}=37 ; 38,5 \%)$. Tempat praktik apoteker paling banyak di daerah Jawa Timur $(n=87 ; 90,6 \%)$ dengan jenis apotek terbanyak adalah apotek swasta $(n=79$; $82,3 \%$ ). Sedangkan kondisi zona COVID-19 di tempat praktik apoteker didominasi zona kuning $(n=31$; $32,3 \%)$.

Tabel 1 Demografi Responden $(\mathrm{n}=96)$

\begin{tabular}{|c|c|}
\hline Item & $\mathrm{n}(\%)$ \\
\hline \multicolumn{2}{|l|}{ Jenis kelamin } \\
\hline Pria & $11(11,5)$ \\
\hline Wanita & $85(88,5)$ \\
\hline \multicolumn{2}{|l|}{ Umur } \\
\hline$\leq 25$ tahun & $11(11,5)$ \\
\hline 26-35 Tahun & $55(57,3)$ \\
\hline 36-45 Tahun & $22(22,9)$ \\
\hline 46-55 Tahun & $5(5,2)$ \\
\hline$\geq 56$ Tahun & $3(3,1)$ \\
\hline \multicolumn{2}{|l|}{ Posisi apoteker } \\
\hline Pemilik apotek & $6(6,3)$ \\
\hline Apoteker pengelola apotek & $53(55,2)$ \\
\hline $\begin{array}{l}\text { Pemilik apotek sekaligus Apoteker } \\
\text { pengelola }\end{array}$ & $21(21,9)$ \\
\hline Apoteker pendamping & $16(16,7)$ \\
\hline \multicolumn{2}{|l|}{ Lama pengalaman kerja } \\
\hline$\leq 1$ Tahun & $15(15,6)$ \\
\hline 2-5 Tahun & $37(38,5)$ \\
\hline 6-10 Tahun & $16(16,7)$ \\
\hline$>10$ Tahun & $28(29,2)$ \\
\hline \multicolumn{2}{|l|}{ Tempat praktik } \\
\hline Jawa Timur & $87(90,6)$ \\
\hline Jawa Barat & $2(2,1)$ \\
\hline NTB & $4(4,2)$ \\
\hline Lainnya (Jawa Tengah, Bali, Papua) & $3(3,1)$ \\
\hline \multicolumn{2}{|l|}{ Jenis apotek } \\
\hline Swasta & $79(82,3)$ \\
\hline BUMN & $9(9,4)$ \\
\hline Waralaba & $8(8,3)$ \\
\hline \multicolumn{2}{|l|}{ Kondisi zona COVID-19 } \\
\hline Hijau & $10(10,4)$ \\
\hline Kuning & $31(32,3)$ \\
\hline Jingga & $26(27,1)$ \\
\hline Merah & $27(28,1)$ \\
\hline Hitam & $2(2,1)$ \\
\hline
\end{tabular}

\section{Dampak yang dirasakan apotek selama pandemi} covid-19

Pandemi COVID-19 memberikan berbagai dampak terhadap apotek. Dari Tabel 2 dapat diketahui bahwa dampak yang dialami oleh 96 apoteker di beberapa apotek di Indonesia, antara lain adanya kekurangan stok obat $(70,8 \%)$, terkendala dalam penyediaan obat $(61,5 \%)$, kenaikan harga beli obat dan alat pelindung diri dari distributor $(90,6 \%)$, dan 
penurunan finansial apotek selama masa pandemi COVID-19 (65,6\%). Apotek mengalami kekurangan stok pada suplemen $(89,86 \%)$, alat pelindung diri $(15,94 \%)$, antibiotik dan antivirus $(2,90 \%)$, serta obatobat lain (antidiabetes, antikonvulsan) $(5,80 \%)$. Selain itu, apotek pernah melayani pasien yang membeli obat dan/atau alat kesehatan dengan jumlah yang banyak $(60,4 \%)$ yang meliputi suplemen dan vitamin $(49 \%)$, alat kesehatan $(45 \%)$, serta obat lainnya (suplemen, vitamin, alat kesehatan dan obat kronis) (6\%). Sedangkan dampak minoritas yang dirasakan dari 96 apoteker tersebut, antara lain adanya peningkatan pengunjung (32,3\%), peningkatan finansial apotek $(20,8 \%)$, pengurangan waktu buka apotek (22,9\%), dan pengurangan staf apotek (PHK) $(10,4 \%)$.

Dampak dari adanya pendemi COVID-19 ini ternyata juga dirasakan oleh beberapa apotek di Kosovo. Hambatan utama yang dirasakan oleh sebagian besar apotek di Kosovo selama pandemi COVID-19 adalah kenaikan harga yang diberlakukan oleh distributor $(\mathrm{n}=208 ; 78,8 \%)$, kepanikan terkait pandemi pasien $(n=202 ; 76,5 \%)$, dan pembelian produk yang tidak perlu dan berlebihan $(\mathrm{n}=190$; 72.0\%) (Hoti et al., 2020).

Pandemi COVID-19 telah mengakibatkan permintaan berlebihan untuk beberapa produk farmasi, yaitu masker, sarung tangan, antibiotik, vitamin, dan pembersih (Dzingirai et al., 2020). Selain itu, permintaan meningkat pada obat-obatan kronik yang akan digunakan pasien selama lockdown di masa pandemi COVID-19 dalam jangka waktu yang tidak pasti. Permintaan berlebihan ini menekan sistem rantai pasokan obat-obatan yang menyebabkan apoteker dan personel apotek mengalami keterbatasan untuk memesan ulang (Dzingirai et al., 2020). Hal ini menyebabkan terjadinya kekurangan stok obat di apotek serta kenaikan harga obat pada distributor.

Tabel 2. Dampak Pandemi Covid-19 yang dirasakan oleh apotek (n=96)

\begin{tabular}{lc}
\hline \multicolumn{1}{c}{ Kondisi yang dialami apotek } & $\mathbf{n}(\%)$ \\
\hline Kekurangan stok obat & $68(70,8)$ \\
\hline Terkendala dalam penyediaan obat & $59(61,5)$ \\
\hline $\begin{array}{l}\text { Kenaikan harga beli obat dan alat } \\
\text { pelindung diri (APD) dari distributor }\end{array}$ & $87(90,6)$ \\
\hline Penurunan pemasukan finansial & $63(65,6)$ \\
selama pandemi & $31(32,3)$ \\
\hline Adanya peningkatan pengunjung & $22(22,9)$ \\
\hline Pengurangan jam buka apotek & $10(10,4)$ \\
\hline Pengurangan staf apotek & \\
\hline *) Satu apotek dapat memilih lebih \\
dari satu kondisi
\end{tabular}

Standar Prosedur Operasional diterapkan apotek di masa pandemi

(SPO) yang

Pelayanan kefarmasian di apotek selama masa pandemi COVID-19 harus mampu mencegah penularan virus COVID-19 sehingga diperlukan acuan dan penerapan langkah dalam pelaksanaannya. Dalam hal ini adalah Standar Prosedur Operasional (SPO) yang mengacu pada Pedoman Kemenkes RI terkait Pedoman Kesiapsiagaan COVID-19 Rev 02 Tahun 2020.

Tabel 3. Standar prosedur operasional (SPO) yang diterapkan apotek selama pandemi $(n=96)$

\begin{tabular}{|c|c|}
\hline SPO yang ditetapkan oleh apotek & n $(\%)$ \\
\hline $\begin{array}{l}\text { Penerapan disinfeksi apotek secara } \\
\text { berkala (4-6 jam sekali) }\end{array}$ & $84(87,5)$ \\
\hline $\begin{array}{l}\text { Penggunaan sekat plastik di loket } \\
\text { pelayanan apotek }\end{array}$ & $77(80,2)$ \\
\hline $\begin{array}{l}\text { Penyediaan wastafel, sabun cuci tangan, } \\
\text { dan hand sanitizer }\end{array}$ & $94(97,9)$ \\
\hline $\begin{array}{l}\text { Staf apotek mencuci tangan dan/atau } \\
\text { menggunakan hand sanitizer sebelum } \\
\text { melayaani pasien }\end{array}$ & $77(80,2)$ \\
\hline Pengukuruhan suhu tubuh staf & $77(80,2)$ \\
\hline Pengunaan APD pada staf & $94(97,9)$ \\
\hline $\begin{array}{l}\text { Penerapan jarak minimal satu meter } \\
\text { antar personel }\end{array}$ & $80(83,3)$ \\
\hline $\begin{array}{l}\text { Pemberlakukan ijn/istirahat bagi staf } \\
\text { yang sedang sakit }\end{array}$ & $95(99,0)$ \\
\hline $\begin{array}{l}\text { *) Satu apotek dapat memilih lebih dari } \\
\text { satu kondisi }\end{array}$ & \\
\hline
\end{tabular}

Dari 96 responden, dapat diketahui SPO yang telah diterapkan dalam apoteknya, antara lain penerapan disinfeksi apotek secara berkala $(87,5 \%)$ dengan mayoritas 4-6 jam sekali, penggunaan sekat plastik di loket pelayanan apotek $(80,2 \%)$, menyediakan wastafel, sabun cuci tangan, dan hand sanitizer $(97,9 \%)$, staf apotek mencuci tangan dan/atau menggunakan hand sanitizer sebelum melayani pasien $(80,2 \%)$, pengukuran suhu tubuh staf $(40,6 \%)$, penggunaan APD pada staf $(97,9 \%, n=94)$, menerapkan jaga jarak minimal satu meter antar personel $(83,3 \%)$, dan diberlakukan istirahat kepada staf yang sedang demam, batuk, dan/atau pilek (99\%).

Alat pelindung diri (APD) yang digunakan oleh para staf dari 94 apotek $(97,9 \%)$ saat melayani pasien antara lain APD lengkap yang meliputi masker, sarung tangan, dan pelindung wajah (13\%), masker dan pelindung wajah (25\%), masker dan sarung tangan $(15 \%)$, hanya menggunakan masker $(44 \%)$, dan pelindung wajah saja (3\%). Pada Pedoman Kemenkes 
RI Tentang Pedoman Kesiapsiagaan COVID-19 Rev 02 Tahun 2020 untuk personil apotek yang berada di konter atau yang berinteraksi dengan pelanggan wajib menggunakan masker, sarung tangan, dan kacamata untuk perlindungan dan seluruh personil apotek wajib menggunakan masker. Dari hasil survei dapat dikatakan bahwa dari 96 responden apotek tersebut hanya $13 \%$ yang menerapkannya.

Dari data tersebut dapat diketahui bahwa 30 apotek dari 96 apotek di Indonesia (31,25\%) sudah menerapkan sistem sanitasi, perlindungan personil, dan pelayanan pelanggan sesuai pada Pedoman Kemenkes RI Tentang Pedoman Kesiapsiagaan COVID-19 Rev 02 Tahun 2020. Sedangkan, 66 apotek lainnya $(69,75 \%)$ masih belum menerapkan pengukuran suhu dan penggunaan APD lengkap.

\section{Metode pelayanan kefarmasian saat pandemi COVID-19}

Sebagai bentuk adaptasi apotek di masa pandemi COVID-19, beberapa apotek melakukan pengembangan terhadap metode pelayanan kefarmasiannya. Metode berbasis teknologi, seperti $e$ pharmacy dapat memberikan nilai tambah dalam sistem perlindungan kesehatan karena lebih nyaman dan mudah diakses di kondisi pandemi ketika konsumen tidak boleh pergi ke luar rumah karena masalah lockdown dan masalah keamanan (Singh et al., 2020).

Tabel 4. Metode Pelayanan kefarmasian di apotek selama pandemi COVID-19 ( $\mathrm{n}=96)$

\begin{tabular}{ll}
\hline \multicolumn{3}{c}{ dilakukan } \\
\hline $\begin{array}{l}\text { Metode pelayanan kefarmasian yang } \\
\text { (delivery) obat ke rumah }\end{array}$ \\
\hline Menyediakan pelayanan resep online & $37(38,5)$ \\
\hline Menyediakan pelayanan swamedikasi & $57(59,4)$ \\
dan pemberian informasi obat kepada & \\
pelanggan melalui online & \\
\hline *) Satu apotek dapat memilih lebih dari & \\
\hline
\end{tabular}

Dari 96 responden apotek, sebanyak 69 apotek $(71,88 \%)$ telah menggunakan pelayanan kefarmasian berbasis teknologi, antara lain menyediakan pembayaran secara virtual $(38,5 \%)$, menyediakan layanan pengiriman (delivery) obat ke rumah (46,9\%), menyediakan pelayanan resep online $(38,5 \%)$, dan menyediakan pelayanan swamedikasi dan pemberian informasi obat kepada pelanggan melalui online $(59,4 \%)$. Pelayanan resep online dan swamedikasi tersebut menggunakan aplikasi chatting (WhatsApp, Telegram, Line), email, aplikasi online lain (Halodoc,
Klikdokter), dan/atau aplikasi video call (Skype, Zoom, Google Meet). Aplikasi chatting paling sering digunakan baik pada pelayanan resep online (50\%) maupun swamedikasi $(87 \%)$.

Di beberapa negara juga sudah mulai menerapkan pelayanan berbasis teknologi. Pada penelitian Bahlol \& Dewey (2020), hanya 49,1\% farmasi komunitas yang sudah mulai menerapkan delivery obat di region Egypt (selatan, timur, utara, dan tengah). Di Netherlands, hanya sejumlah kecil apotek yang menggunakan telefarmasi, seperti panggilan video selama edukasi dan konseling pasien (Koster et al., 2020). Penggunaan layanan resep online di Zimbabwe dengan aplikasi WhatsApp merupakan cara yang umum dilakukan. Apoteker melakukan konseling menggunakan aplikasi tersebut dan kemudian melakukan delivery obat yang dikelompokkan. Personel yang mengirimkan obat menggunakan APD lengkap termasuk masker dan sarung tangan. Penggunaan resep online ini cukup efektif untuk mengurangi resiko penularan COVID-19 yang mana patogen dapat menyebar melalui kontak antara apoteker dan pasien dalam penyerahan resep secara langsung. Untuk mendukung adanya telefarmasi di apotek maka pembayaran dapat dilakukan secara non-tunai menggunakan platform seluler (Dzingirai et al., 2020).

\section{KESIMPULAN}

Dari hasil penelitian ini dapat disimpulkan bahwa adanya pandemi COVID-19 memiliki dampak terhadap pelayanan apotek diantaranya penetepan protokol kesehatan dan perubahan model pelayanan kefarmasian seperti pelayanan e-pharmacy.

\section{UCAPAN TERIMA KASIH}

Penulis mengucapkan terima kasih kepada Bapak dan Ibu dosen yang telah membimbing dan memberi masukan dalam pengolahan data, para responden, serta seluruh pihak yang terlibat dalam penelitian ini.

\section{DAFTAR PUSTAKA}

Bahlol, M., and Dewey, R.S. (2020) 'Pandemic preparedness of community pharmacies for COVID-19', Research in Social and Administrative Pharmacy, 17(1), pp.18881896.

doi: https://doi.org/10.1016/j.sapharm.2020.05.009.

Bahrun, S., Alifah, S., Mulyono, S. (2017) 'Rancang bangun sistem informasi survey pemasaran dan penjualan berbasis web', Jurnal Transistor Elektro Dan Informatika, 2(2), pp. 81-88. doi: http://dx.doi.org/10.30659/ei.2.2.\%25p 
Dzingirai, B., Matyanga, C.M.J., Mudzviti, T., Siyawamwaya, M., Tagwireyi, D. (2020) 'Risks to the community pharmacists and pharmacy personnel during COVID-19 pandemic: perspectives from a low-income country', Journal of Pharmaceutical Policy and Practice, 13(1), pp. 1-6. doi: https://doi.org/10.1186/s40545-020-00250-2

Fallucchi, F., Faravelli, M., Quercia, S. (2020) 'Fair allocation of scarce medical resources in the time of COVID-19: what do people think?', Journal of Medical Ethics, 47(1), pp. 3-6. doi: 10.1136/medethics-2020-106524

Hedima, E. W., Adeyemi, M. S., Ikunaiye, N. Y. (2020) 'Community pharmacists: on the frontline of health service against COVID-19 in LMICs', Research in Social and Administrative Pharmacy, 17(1), pp. 19641966.

doi:https://doi.org/10.1016/j.sapharm.2020.04. 013.

Hoti, K., Jakupi, A., Hetemi, D., Raka, D., Hughes, J., Desselle, S. (2020) 'Provision of community pharmacy services during COVID-19 pandemic: a cross sectional study of community pharmacists experiences with preventative measures and sources of information', International Journal of Clinical Pharmacy, 42(4), pp. 1197-1206. doi: 10.1007/s11096-020-01078-1

International Pharmaceutical Federation. (2017) 'Fip Statement of Policy Role of Pharmacist in disaster management'. The Hague, the Netherlands: FIP.

Pedoman Kemenkes RI. (2020) Pedoman Kesiapsiagaan COVID-19 Rev 02 Tahun 2020 2020.
Koster, E. S, Philbert, D., Bouvy, M. L. (2020) Impact of the COVID-19 epidemic on the provision of pharmaceutical care in community pharmacies', Research in Social and Administrative Pharmacy, 17(1), pp. 10-12. doi: https://doi.org/10.1016/j.sapharm.2020.07.001

Peraturan Kementrian Kesehatan RI. (2014) 'Peraturan Menteri Kesehatan Republik Indonesia nomor 65 tahun 2015 tentang standar pelayanan fisioterapi.

Gadea, A. S., Santos, G. D., Alobid, I., Mullol, J., \& Sánchez, F. M. (2021) 'Errors and biases in meta-analysis of the prevalence of olfactory dysfunction in patients with COVID-19', SAGE Journals, 164(2), pp. 455-456. doi:. https://doi.org/10.1177/0194599820951133

Singh, H., Majumdar, A., Malviya, N. (2020), 'Epharmacy impacts on society and pharma sector in economical pandemic situation: a review', Journal of Drug Delivery and Therapeutics, 10(3-s), pp. 335-340. doi: https://doi.org/10.22270/jddt.v10i3-s.4122

World Health Organization. (2020), Coronavirus $\begin{array}{llll}\text { viewed } & 4 & \text { Oktober } & \end{array}$ https://www.who.int/healthtopics/coronavirus\#tab=tab_3.

Zheng, S. Q., Yang, L., Zhou, P. X., Li, H. B., Liu, F., Zhao, R. S. (2020), 'Recommendations and guidance for providing pharmaceutical care services during COVID-19 pandemic: a China perspective. In Research in Social and Administrative Pharmacy', 17(1), 1819-1824. doi:https://doi.org/10.1016/j.sapharm.2020.03. 012 . 